\title{
Adenomyomatosis of the Common Bile Duct and Ampulla of Vater
}

\author{
Catarina Gouveia $^{\mathrm{a}}$ Catarina Fidalgo $^{\mathrm{a}}$ Rui Loureiro ${ }^{\mathrm{a}}$ Helena Oliveira $^{\mathrm{b}}$ \\ Rui Maioc Marília Cravo ${ }^{\mathrm{a}}$ \\ ${ }^{a}$ Gastroenterology Department, Beatriz Ângelo Hospital, Loures, Portugal; b Pathology Department, Beatriz Ângelo \\ Hospital, Loures, Portugal; ' General Surgery Department, Beatriz Ângelo Hospital, Loures, Portugal
}

\section{Keywords}

Adenomyomatous hyperplasia · Adenomyosis .

Adenomyomatosis · Adenomyoma $\cdot$ Ampulla of Vater .

Common bile duct

\section{Abstract}

Adenomyomatosis is a rare benign lesion that has been observed in different sites throughout the gastrointestinal tract, most frequently in the gallbladder. Few cases have been described in the stomach, small bowel, bile ducts, and ampullary region. Adenomyomas of the vaterian system (ampulla and common bile duct) have important clinical consequences, since the majority of these lesions present with biliary tract obstruction and mimic malignant behavior. As a consequence, considering the diagnostic difficulty of these lesions, patients are often treated with extensive surgery (pancreaticoduodenectomy). We report 2 cases of adenomyomatosis: one of the ampulla of Vater and the other of the common bile duct, as well as a review of reported cases in the literature. Both of our patients presented with epigastralgia and had laboratory or endoscopic evidence of biliary obstruction. Both patients underwent endoscopic ultrasound, one of them with fine-needle aspiration; however, it was not possible to exclude the possibility of cancer. The diagnosis of adenomyoma was only confirmed by the surgical specimen after pancreaticoduodenectomy.

(C) 2020 Sociedade Portuguesa de Gastrenterologia Published by S. Karger AG, Basel

karger@karger.com www.karger.com/pjg

Karger $\stackrel{\text { ' }}{5}$

BOPEN ACCESS
(C) 2020 Sociedade Portuguesa de Gastrenterologia Published by S. Karger AG, Basel

This article is licensed under the Creative Commons AttributionNonCommercial-NoDerivatives 4.0 International License (CC BY NC-ND) (http://www.karger.com/Services/OpenAccessLicense). Usage and distribution for commercial purposes as well as any distribution of modified material requires written permission.

\section{Adenomiomatose da Via Biliar Principal e Ampola de Vater}

\section{Palavras-Chave}

Hiperplasia adenomiomatosa $\cdot$ Adenomiose .

Adenomiomatose - Adenomioma - Ampola de Vater .

Via biliar principal

\section{Resumo}

A adenomiomatose é uma lesão benigna rara que tem sido observada em diferentes locais do trato gastrointestinal, mais frequentemente na vesícula biliar. Poucos casos foram descritos no estômago, intestino delgado, vias biliares e ampola de Vater. Os adenomiomas do sistema de Vater (ampola e via biliar principal) têm importantes consequências clínicas, uma vez que a maioria dessas lesões se apresenta com obstrução biliar, sugerindo comportamento maligno. Como consequência, na maioria dos casos, e considerando a dificuldade diagnóstica destas lesões, os doentes são frequentemente submetidos a cirurgia extensa (pancreaticoduodenectomia). Reportamos dois casos de adenomiomatose da ampola de Vater e via biliar principal, bem como uma revisão dos casos descritos na literatura. Os doentes apresentaram-se com queixas de epigastralgia e evidência laboratorial ou endoscópica de obstrução biliar. Em ambos os casos foi re- 
alizada ultrassonografia endoscópica e em um deles punção aspirativa por agulha fina, não tendo sido possível excluir a possibilidade de malignidade. $O$ diagnóstico de adenomioma foi apenas confirmado na peça cirúrgica após pancreaticoduodenectomia.

(C) 2020 Sociedade Portuguesa de Gastrenterologia Publicado por S. Karger AG, Basel

\section{Introduction}

Adenomyomatosis (adenomyomatous hyperplasia, adenomyosis, or adenomyoma) is a rare benign lesion that has been observed in different sites throughout the gastrointestinal tract, most frequently in the gallbladder [1]. Adenomyomatosis of the gallbladder is most often an incidental finding during cholecystectomy performed for another reason with a prevalence of 1-9\%, and large autopsy series report a prevalence of $7 \%[2,3]$. Few cases have been described in the stomach, small bowel, bile ducts, and ampullary region. Adenomyomas of the vaterian system (ampulla of Vater $[\mathrm{AV}]$ and common bile duct [CBD]), unlike its counterparts in the rest of the digestive tract, have important clinical consequences, since the majority of these lesions present with biliary tract obstruction and mimic malignant behavior [1]. As consequence, despite being a benign lesion in most cases, patients are often treated with extensive surgery (pancreaticoduodenectomy). We report 2 cases of adenomyomatosis: one of the AV and the other of the $\mathrm{CBD}$, as well as a review of cases reported in the lit-

Table 1. Full blood workup (case 1)

\begin{tabular}{lr}
\hline Parameter & Value \\
\hline Hemoglobin, g/dL & 13.0 \\
White blood cells, $\times 10^{9} / \mathrm{L}$ & 5,000 \\
Platelets, $\times 10^{9} / \mathrm{L}$ & 331,000 \\
Urea, mg/dL & 18 \\
Creatinine, mg/dL & 0.67 \\
AST, IU/L & 72 \\
ALT, IU/L & $\mathbf{8 6}$ \\
ALK, IU/L & 47 \\
GGT, IU/L & 26 \\
Total bilirubin, mg/dL & 0.26 \\
Conjugated bilirubin, mg/dL & 0.17 \\
Amylase, IU/L & 70 \\
Serum sodium, mg/dL & 140 \\
Serum potassium, mg/dL & 4 \\
C-reactive protein, mg/dL & 0.1 \\
CA 19.9 & 6.9 \\
\hline
\end{tabular}

erature. Both of our patients presented with epigastralgia and had laboratory or endoscopic evidence of biliary obstruction. The diagnosis of adenomyoma was only confirmed by the surgical specimen after cephalic pancreaticoduodenectomy.

\section{Case Reports}

Case 1

A 70-year-old woman with previous laparoscopic cholecystectomy for gallstones and a history of hypertension and dyslipidemia was referred to a gastroenterologist for epigastralgia and an abnormal abdominal CT scan, which revealed CBD dilatation $(22 \mathrm{~mm})$ with progressive reduction in size, without any AV or pancreas distortion. She had no family history of cancer and no jaundice. Laboratory workup showed elevated transaminases: $72 \mathrm{IU} / \mathrm{L}$ aspartate transaminase (AST) and $86 \mathrm{IU} / \mathrm{L}$ alanine transaminase (ALT). Alkaline phosphatase (ALK), $\gamma$-glutamyltransferase (GGT), total and conjugated bilirubin, and amylase were within normal ranges. Carcinogen antigen 19.9 (CA 19.9) was normal. She had a normal complete blood count and no elevation in acute-
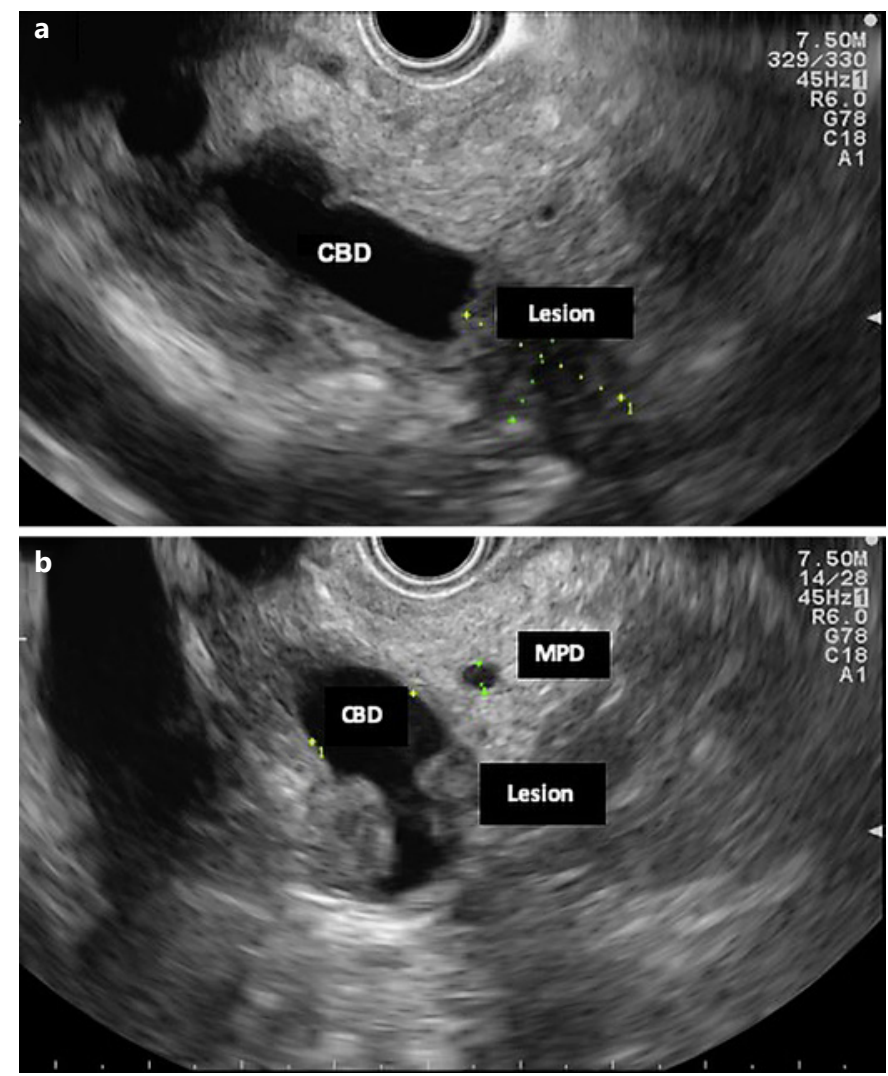

Fig. 1. EUS (linear endoscope) reveals dilated CBD and a poorly defined hypoechogenic mass in its distal portion (a). b Mass in the distal common bile duct. 
phase reactants (Table 1). A magnetic resonance cholangiopancreatography (MRCP) confirmed CBD dilatation with a localized stenosis $1 \mathrm{~cm}$ above the ampulla. A subsequently performed endoscopic ultrasound (EUS) showed a dilated CBD $(16 \mathrm{~mm})$ and a poorly defined hypoechogenic mass $(1.5 \times 1.9 \mathrm{~cm})$ in the distal part. There was neither main pancreatic duct (MPD) or parenchyma involvement nor evidence of lymph node, ascites, or left hepatic lobe alterations (Fig. 1). A duodenoscopy showed a bulging AV with normal mucosa (Fig. 2). EUS-guided fine-needle aspiration (FNA) or brush cytology/biopsies obtained by endoscopic retrograde cholangiopancreatography (ERCP) was not performed because a negative or inconclusive histology would not change our therapeutic approach, since malignancy suspicion was high. The case was discussed at a digestive oncology multidisciplinary meeting and in consideration of the diagnostic hypothesis of cholangiocarcinoma of the distal bile duct and after discussion with the patient, she was submitted to a cephalic pancreaticoduodenectomy, which was performed 1 month later. Surgery was uneventful, and the patient was discharged on the 15th postoperative day. Macroscopic examination of the surgical specimen showed a bulging AV, CBP dilatation, and a subepithelial lesion without duodenal wall or pancreas invasion (Fig. 3). Histologically, the lesion consisted

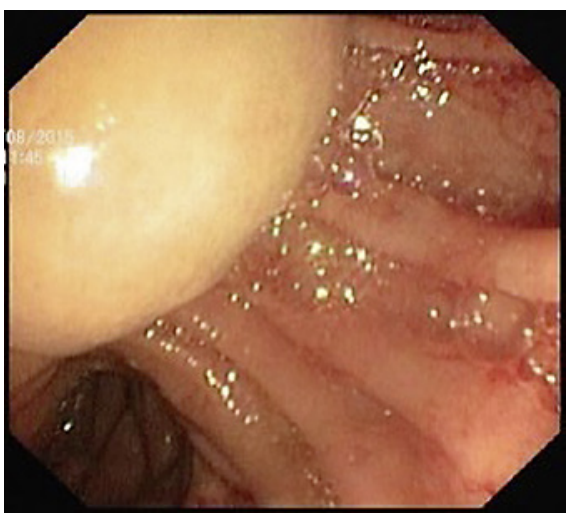

Fig. 2. Duodenoscopy showing bulging of the ampulla of Vater with a normal mucosa. of hyperplastic glandular lobules surrounded by muscle fibers and fibroblasts, suggestive of adenomyomatosis of the CBP and AV (Fig. 4). At the 3-year follow-up, she was asymptomatic and without laboratory abnormalities.

\section{Case 2}

A 58-year-old man with a history of peptic ulcer disease and gastroesophageal reflux was referred to a gastroenterologist after an upper GI endoscopy, performed for epigastralgia. A protruding ampulla with a normal mucosa was described (Fig. 5). He had no family history of cancer and had no jaundice. Laboratory workup showed elevated transaminases with AST of $52 \mathrm{IU} / \mathrm{L}$ and ALT of
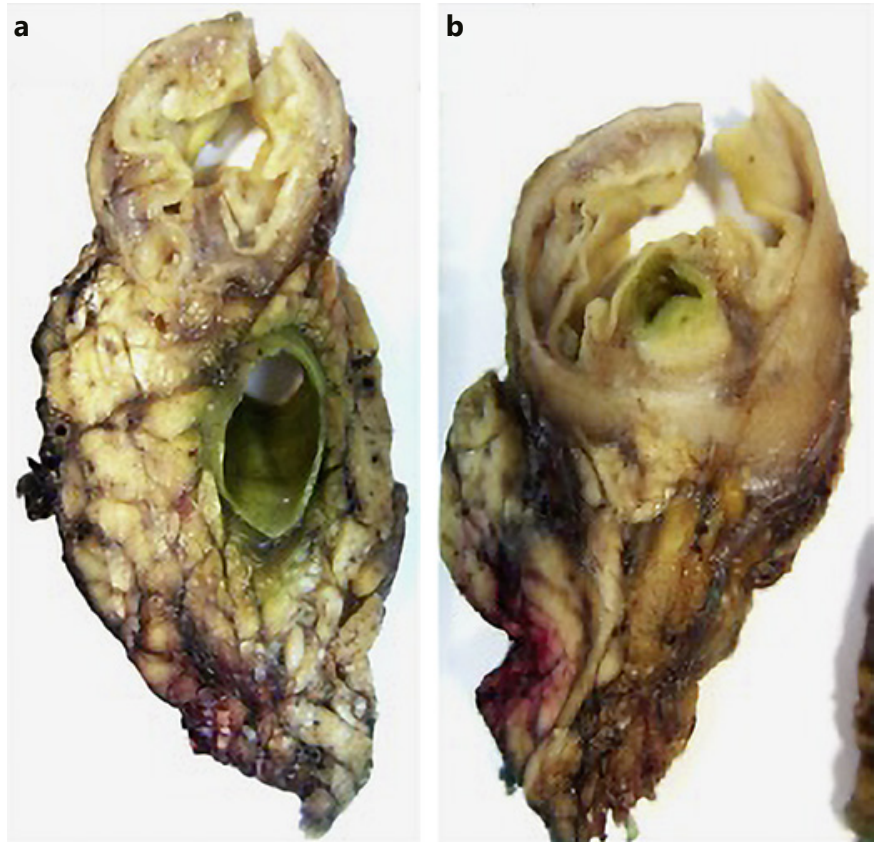

Fig. 3. Macroscopic examination of a surgical specimen shows bulging of the ampulla and CBD dilatation (a) and a subepithelial lesion without duodenal wall or pancreas invasion (b).
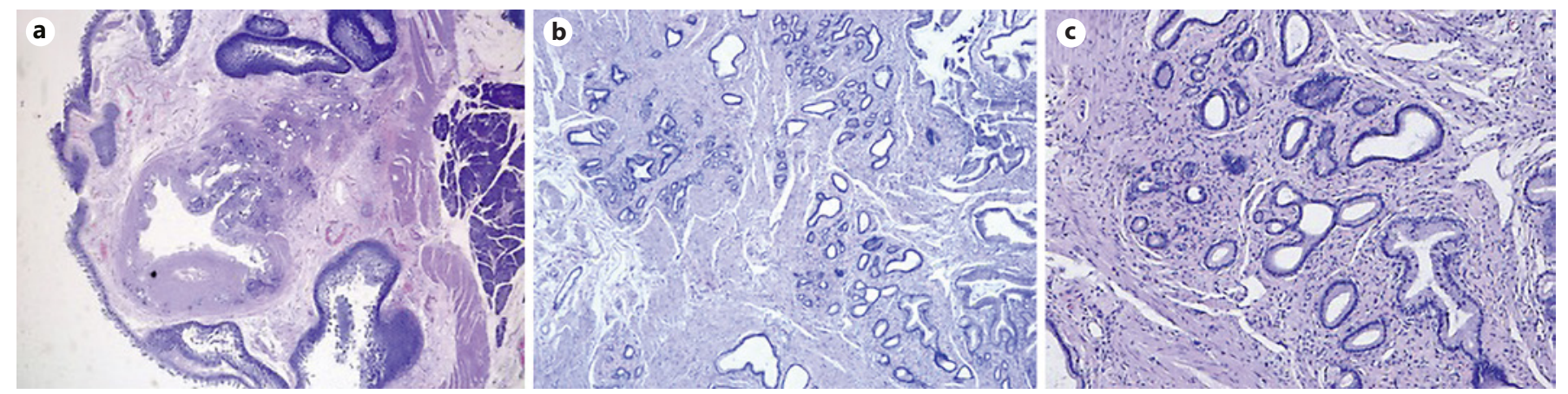

Fig. 4. Microscopic examination of surgical specimens. H\&E. a. Low magnification with subepithelial lesion. b $\times 4$. c Hyperplastic glandular lobules surrounded by muscle fibers and fibroblasts. $\times 10$. 


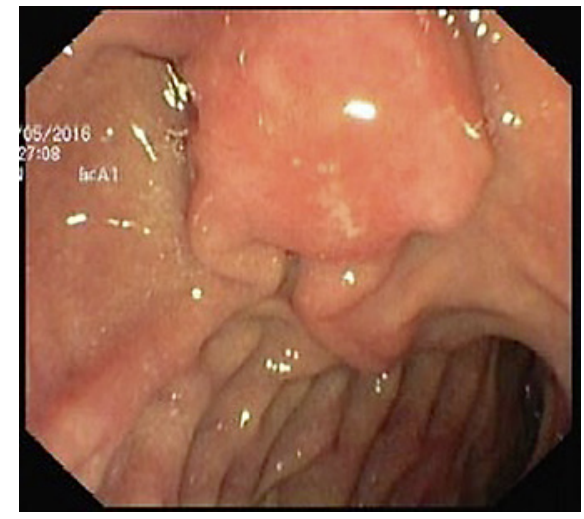

Fig. 5. Duodenoscopy with protruding ampulla with a normal mucosa.
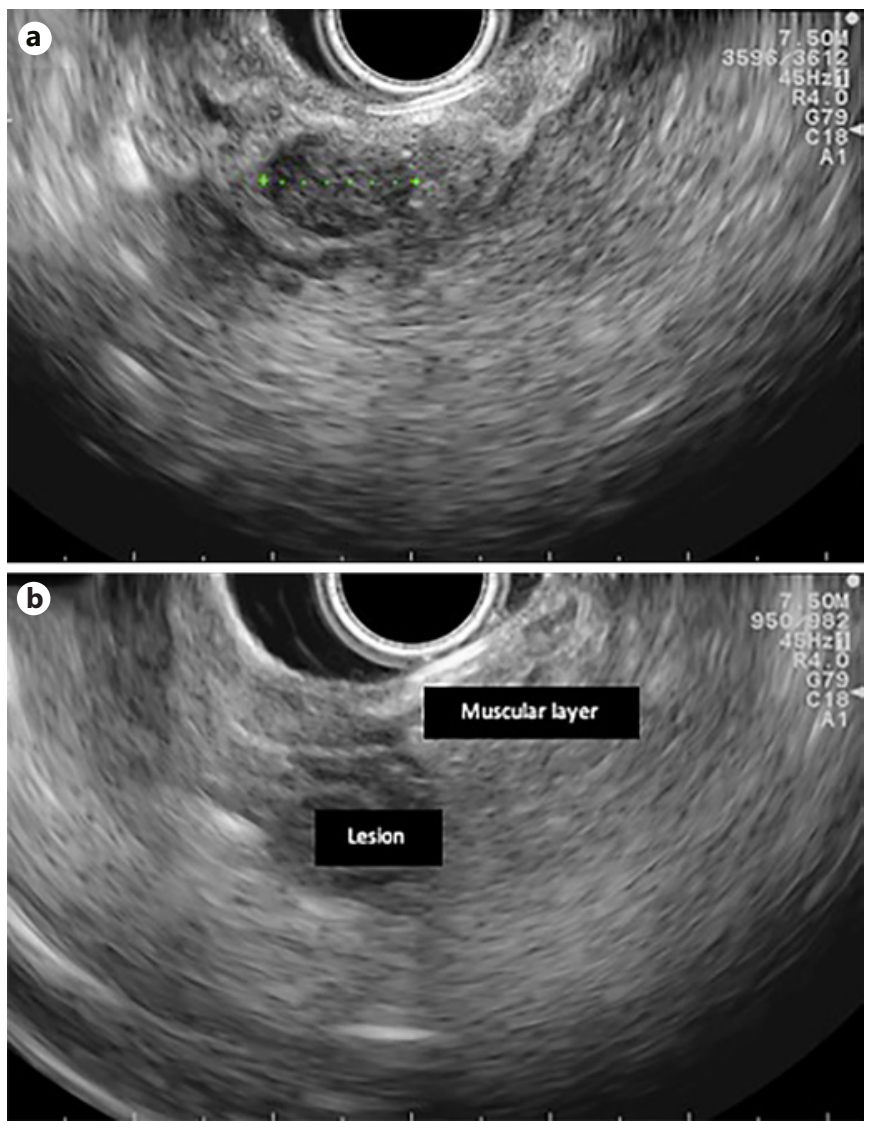

Fig. 6. EUS features (linear endoscope): 12-mm hypoechogenic mass in the ampulla area (a) and a lesion with duodenal-wall muscular-layer involvement (b).

64 IU/L. ALK, GGT, total and conjugated bilirubin, and amylase were within normal ranges. A complete blood count was normal, and acute-phase reactants were not elevated. CA 19.9 was normal (Table 2). EUS showed a 12-mm, poorly defined, hypoechogenic mass in the AV area, with involvement of the distal CBD and the

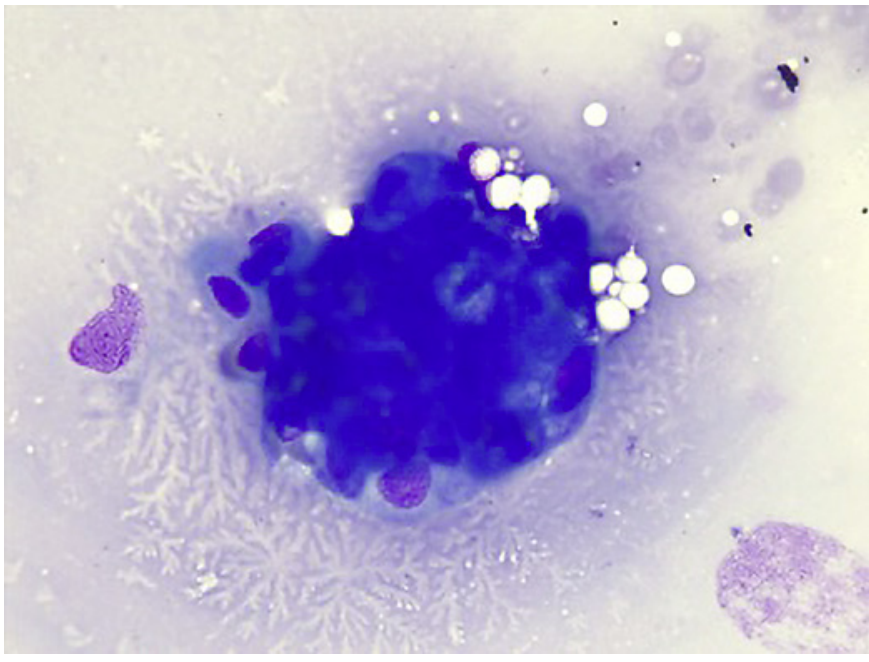

Fig. 7. Cytology examination showed groups of epithelial cells: some with benign characteristics and others with nuclear overlap and increased nuclei in favor of epithelial dysplasia without obvious carcinoma characteristics.

muscular layer of the duodenal wall. There was no evidence of CBD dilatation or pancreatic involvement (Fig. 6). FNA was performed. Cytological examination showed groups of epithelial cells: some with benign characteristics and others with nuclear overlap and increased nuclei, in favor of epithelial dysplasia, without obvious carcinoma characteristics (Fig. 7). The case was discussed at a digestive oncology multidisciplinary meeting; considering the diagnostic hypothesis of ampulloma and after discussing the case with the patient, she was submitted to cephalic pancreaticoduodenectomy, which was performed 1 month later. The surgery was uneventful, and the patient was discharged on the 8th postoperative day. Macroscopic examination of the surgical specimen showed a white and firm tumor of $1.6 \mathrm{~cm}$ in largest diameter (Fig. 8). Histologically (Fig. 9), there was a slight CBD and MPD dilatation and some inflammatory infiltrate. The ampulla consisted of aggregates of ductal proliferation surrounded by fibrosis, which had continuity with the muscular layer of the duodenal wall. There were some areas with enlarged and stratified nuclei in favor of reactive atypia. These findings were consistent with the diagnosis of AV adenomyomatosis. At the 2-year follow-up, she was asymptomatic and without analytical alterations.

\section{Discussion}

According to the WHO classification, adenomyoma is a benign lesion with no premalignant risk, defined as duct-like structures accompanied by hyperplasia of smooth muscle bundles [4]. The real incidence of these lesions is difficult to settle as different names are used to designate the same histological lesion [1]. Published series of unselected postmortem examinations report an in- 
Fig. 8. Macroscopic examination of a surgical specimen: bulging ampulla (a) and white and firm tumor $1.6 \mathrm{~cm}$ in the largest diameter (b).
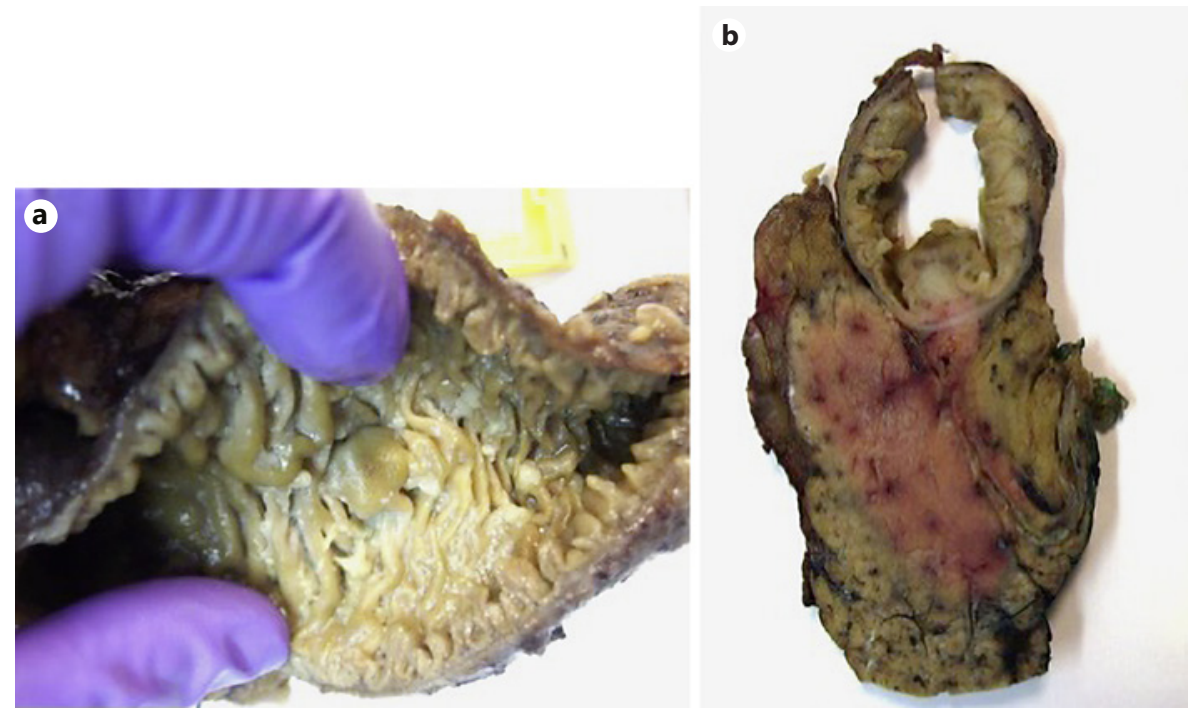

cidence of $50-70 \%$ of small adenomyomas of the vaterian system $(<5 \mathrm{~mm})$, a high percentage of cases having no relevant associated clinical history. Symptomatic lesions reported in the medical literature are much rarer and reported mostly as single case reports $[5,6]$. To our knowledge, this is the first literature review regarding AV and CBD adenomyomatosis. Our 2 cases were a 70-year-old woman and 58-year-old man with laboratory or endoscopic evidence of biliary obstruction, in whom preoperative diagnosis was ambiguous, and the diagnosis of adenomyoma was only confirmed by the surgical specimen after pancreaticoduodenectomy.

A PubMed search conducted using the key words "adenomyomatous hyperplasia," "adenomyoma," "adenomyosis," "adenomyomatosis," and "ampulla of Vater" or "common bile duct," revealed 61 case reports (from 1987 to July 2018) eligible for analysis (Table 3). Regarding published cases, almost half of the patients were male $(n=29,48 \%)$, and their mean age was 62 years (range 18-81 years). Forty-nine patients had AV adenomyoma $(80 \%)$, and 12 had CBD adenomyoma (20\%). Patients presented with jaundice $(n=22 / 61)$, abdominal pain $(n=$ $25 / 61)$, nausea and vomiting $(n=3 / 61)$, acute pancreatitis $(n=2 / 61)$ - both with AV lesions, loss of appetite $(n=$ $3 / 61)$, and fatigue $(n=1)$. Fifteen patients $(25 \%)$ were asymptomatic, and the finding was incidental. For 1 patient, clinical presentation was not mentioned. Nineteen patients had cholestasis/conjugated hyperbilirubinemia, 10 had transaminase, ALK, or GGT elevation with normal bilirubin, 2 patients had elevated amylase and lipase, and 3 patients had normal liver tests. In 26 cases, laboratory workup was not reported. Imaging (abdominal CT,
Table 2. Full blood workup (case 2)

\begin{tabular}{lr}
\hline Parameter & Value \\
\hline Hemoglobin, g/dL & 15.2 \\
White blood cells, $\times 10^{9} / \mathrm{L}$ & 6,000 \\
Platelets, $\times 10^{9} / \mathrm{L}$ & 219,000 \\
Urea, mg/dL & 18 \\
Creatinine, mg/dL & 0.83 \\
AST, IU/L & 52 \\
ALT, IU/L & $\mathbf{6 4}$ \\
ALK, IU/L & 40 \\
GGT, IU/L & 21 \\
Total bilirubin, mg/dL & 0.44 \\
Conjugated bilirubin, mg/dL & 0.12 \\
Amylase, IU/L & 90 \\
Serum sodium, mg/dL & 136 \\
Serum potassium, mg/dL & 3.9 \\
C-reactive protein, mg/dL & 0.2 \\
CA 19.9 & 1.3 \\
\hline
\end{tabular}

MRI, and MRCP) and endoscopic (ERCP and upper GI EUS) features more frequently found were CBD or MPD dilation, tumor-like mass in the papilla region or distal CBD, CBD stenosis, intrahepatic biliary tract dilation, and bulging papilla (in patients with ampullary lesions). There was no preoperative or intraoperative histological diagnosis in 26 patients. In the other patients, several different diagnoses were made: 2 adenomas, 5 adenocarcinomas, 2 cases of inflammatory changes, 3 cases of dysplasia, 3 cases of atypical cells, 3 cases of muscular and glandular proliferation, 1 case of suspected adenomyoma, 8 adenomyomas, 1 adenomyoma with dysplasia, and 1 

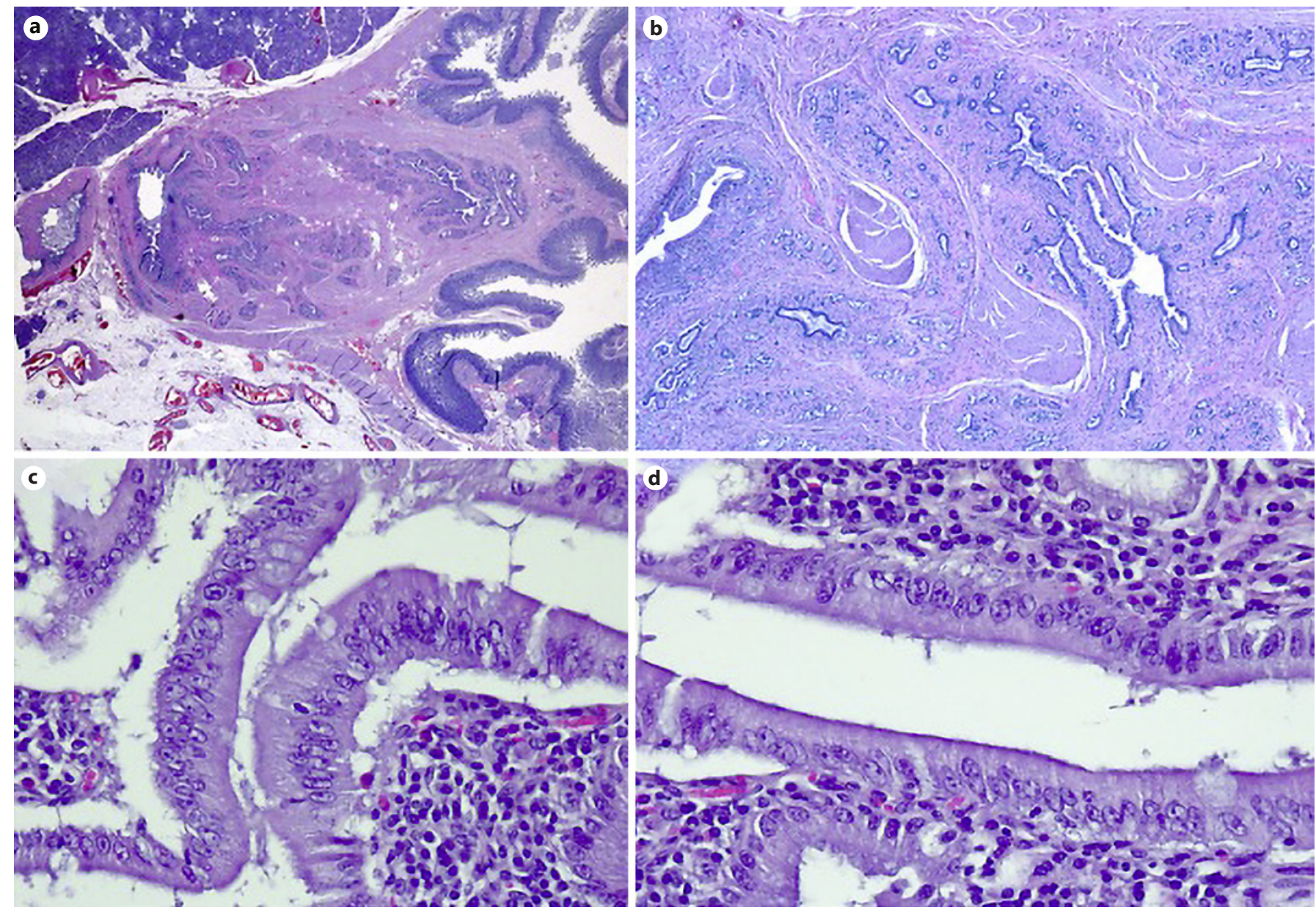

Fig. 9. Microscopic examination of the specimen. H\&E. a Low magnification showing that the lesion consisted of aggregates of ductal proliferation surrounded by fibrosis and had continuity with the muscular layer of the duodenal wall. b Low magnification

demonstrates slight dilatation of $\mathrm{CBD}$ and MPD, and chronic periductal inflammatory infiltrate. c, d Areas with enlarged and stratified nuclei in favor of reactive changes. $\times 40$.

patient without malignant cells. Besides these pre-/intraoperative diagnoses, in 6 patients, intraoperative frozen sections revealed adenomyomatosis of ampullary, glandular, and muscular proliferation, muscle-cell hyperplasia, uncertain for malignancy, atypical cells, and negative for malignancy, respectively. Consequently, only in 9 patients (15\%), adenomyoma was diagnosed pre-/intraoperatively. These patients were submitted to endoscopic papillectomy $(n=4)$, surgical papillectomy $(n=1)$, and close observation $(n=4)$. Forty-one patients $(67 \%)$ underwent duodenopancreatectomy, 7 patients were submitted to endoscopic ampullectomy, 2 patients underwent surgical ampullectomy, 2 had local surgical/extensive excision, 2 had $\mathrm{CBD}$ surgical resection, 1 had endoscopic mass excision using biopsy forceps, and 4 patients received close observation with repeated endoscop-

ic observations (lesions did not change with time, but the duration of follow-up time is mentioned in the case report).

The diagnosis of adenomyoma of the vaterian system (AV and CBD) is challenging. Patients often present with signs of biliary obstruction and cholestasis, and preoperative imaging (CT, MRI, and MRCP) frequently shows common bile duct obstruction or a tumor-like mass. Endoscopic biopsies, EUS-FNA and brush cytology show most of the time atypical cells, dysplasia, or even malignancy. In retrospect, these findings are thought to be secondary to AV and CBD endoscopic manipulation (biopsy, brush cytology, and sphincterotomy), and may contribute to the diagnostic difficulties. The overall accuracy for preoperative histopathological diagnosis with endoscopic forceps biopsies in patients with AV tumors was reported 


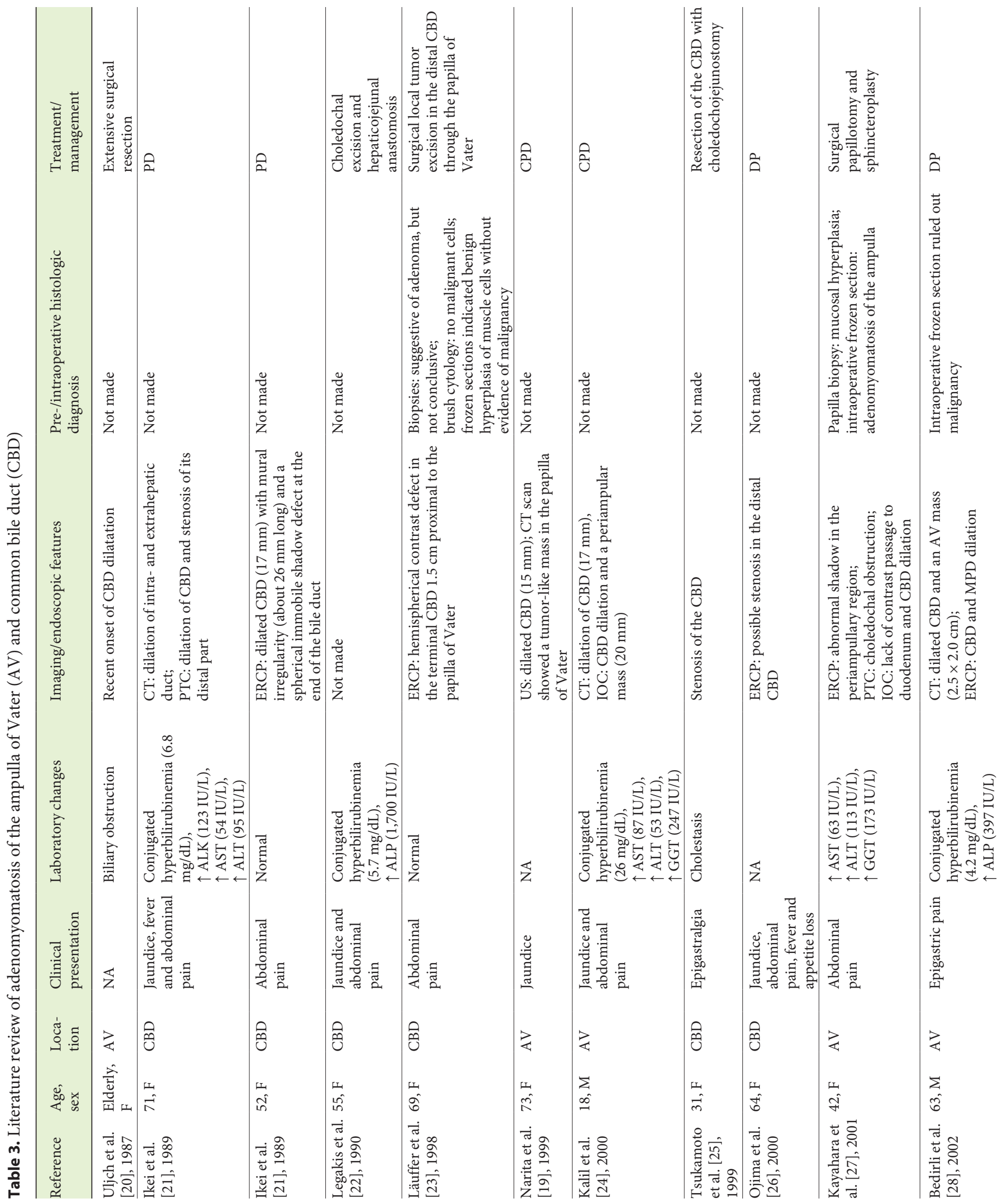




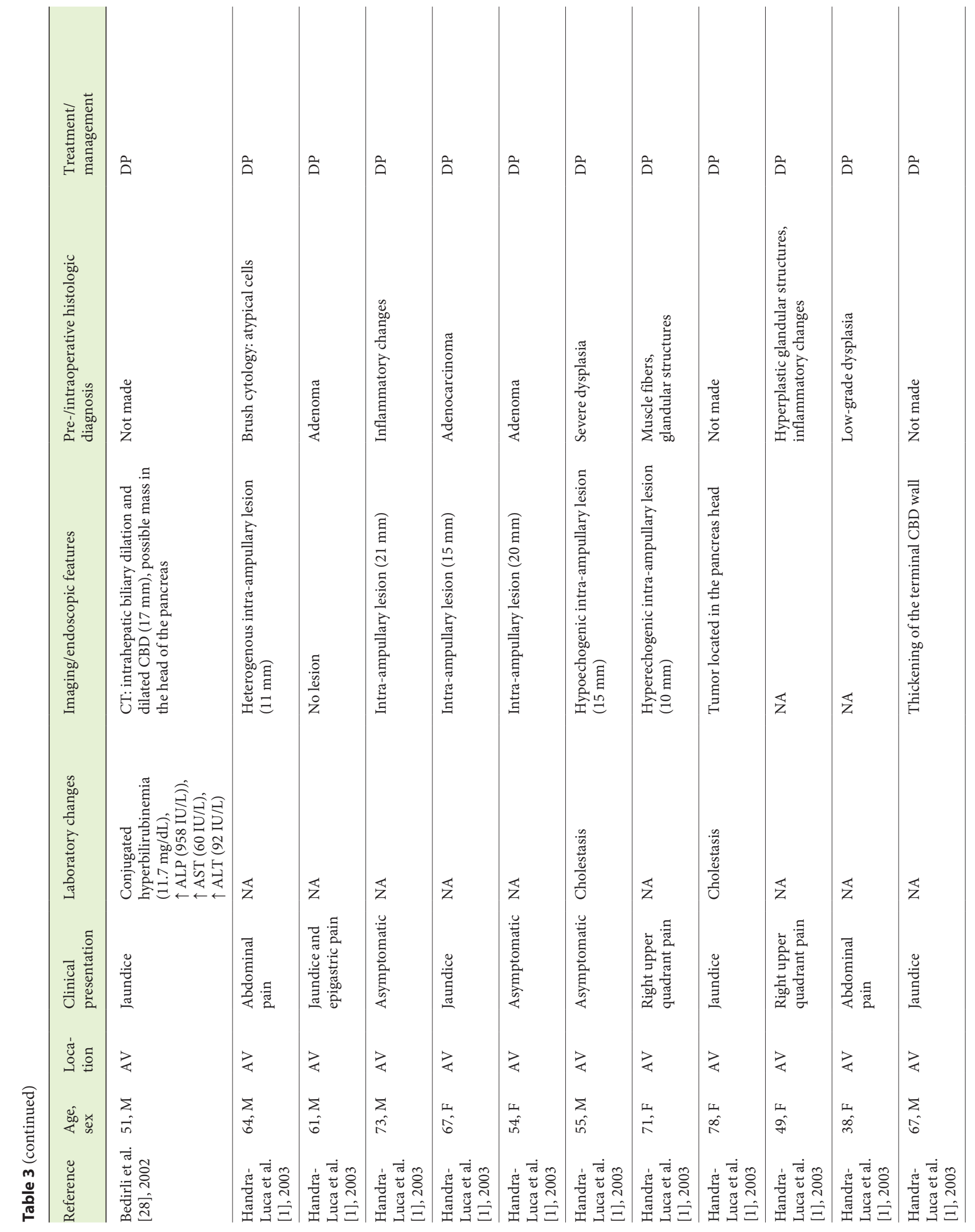




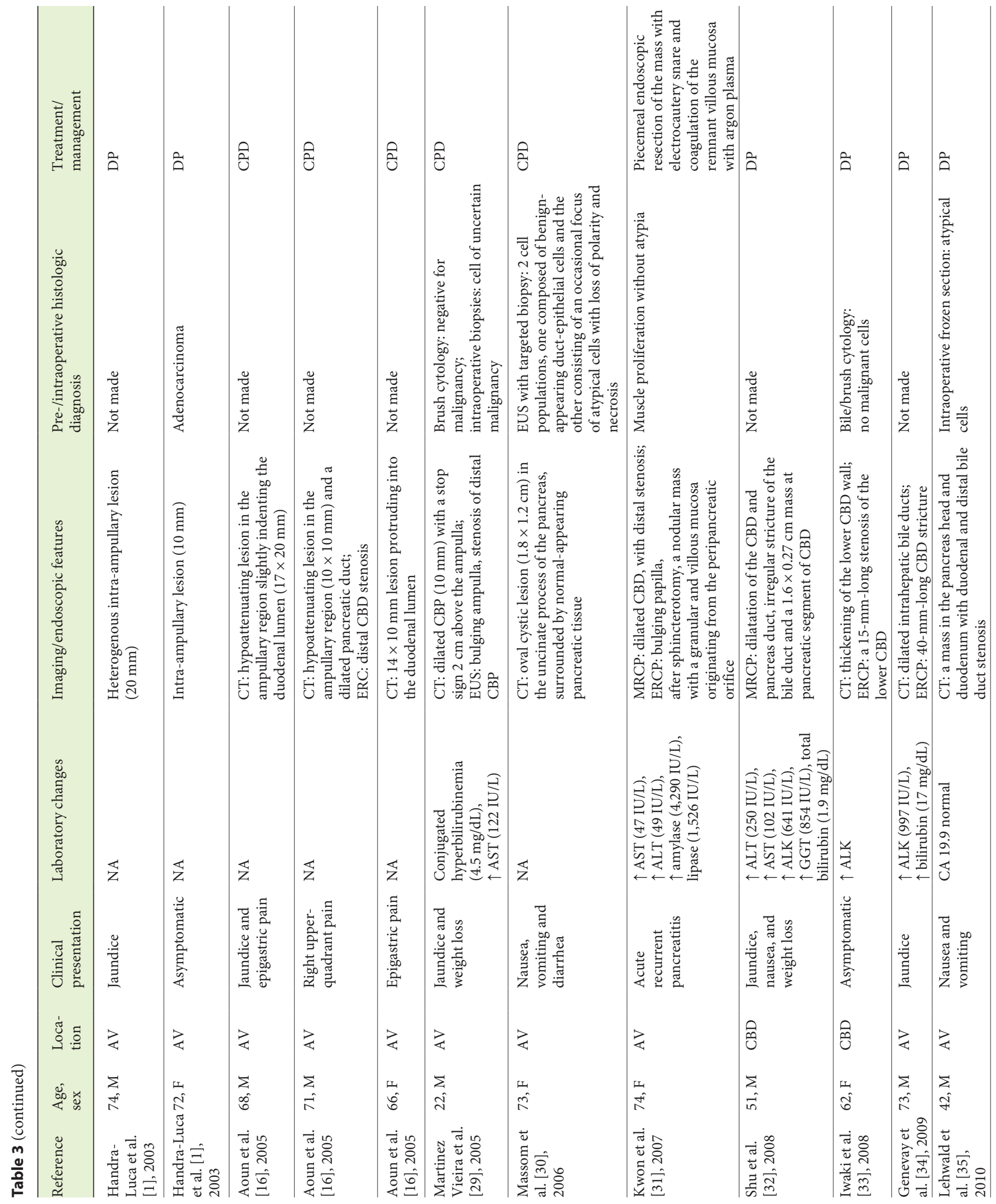









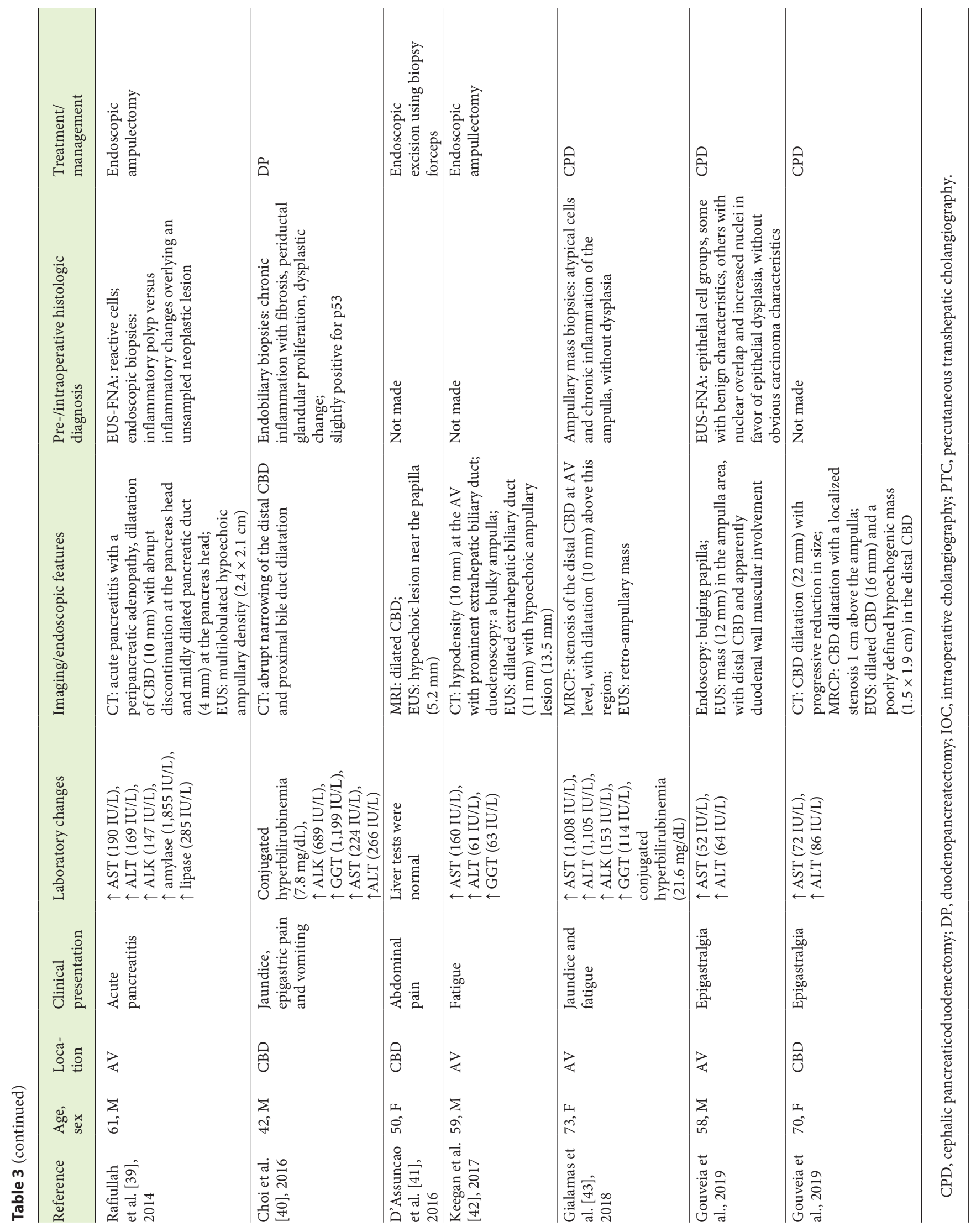


as $62 \%$ by Menzel et al. [7]. Hammarström et al. [8], in a study including 3,131 patients submitted to ERCP, showed that a correct endoscopic diagnosis was only made in 2 of the 4 patients with adenomyoma. ERCP also allows for brush cytology and intraductal biopsy performance. The sensitivity of brush cytology and intraductal biopsy in diagnosing malignant biliary strictures are reported as 45 and $48.1 \%$ respectively, and both techniques are almost $100 \%$ specific. A combination of both modalities modestly increased the sensitivity to $59.4 \%$ [9]. To overcome this limitations, Kim et al. [10] and Uchida et al. [11] showed that repeated testing (multiple cytology tests) via endoscopic nasobiliary drainage increased the cumulative diagnostic rate, with a sensitivity of $95 \%$ with 6 repeated exams [10, 11]. Logrono et al. [12], who analyzed 183 pancreatobiliary brush specimens from 2 university hospitals, showed that the possibility of malignancy with no evidence of malignancy from repetitive endoscopic biopsy was lower than 10\%. EUS-FNA can be performed for distal extrahepatic bile duct strictures, with a sensitivity and negative likelihood ratio for diagnosis of malignancy of $66 \%$ and 0.34 , respectively [13]. Furthermore, EUS-FNA can be performed in ampullary and distal CBD masses with an overall accuracy of $100 \%$, with a sensitivity, specificity, and positive and negative predictive values of $100 \%$ [14]. Intraoperative frozen sections from the mass can usually differentiate whether the lesion is benign or malignant (adenomyoma and adenocarcinoma). However, most pathologists have limited experience with frozensection adenomyomas [15]. Macroscopically, adenomyoma of the ampullary region usually appears as a rounded, well-defined, intraluminal lesion arising from the CBD wall, although some case reports have described a diffuse form infiltrating the CBD wall which resembles a stenotic lesion [16]. The histological aspect of adenomyoma is characterized by multiple lobules of glands, mainly located in the muscle layers of the vaterian system. The lobular formations consist of small glands arranged around a larger gland and surrounded by myofibroblastic and fibroblastic proliferation. This mesenchymal component is rather composed of fibroblasts and myofibroblasts (with smooth muscle actin expression but without desmin expression), but it may contain sparse smooth muscle cells [1]. The histogenesis of adenomyoma and adenomyomatous hyperplasia is still a subject of controversy. The most widely accepted hypothesis is that these lesions may represent a form of incomplete heterotopic pancreas (type III), as described by von Heinrich in 1909 [1]. The presence of hyperplastic smooth muscle tissue can be explained by secondary muscle proliferation caused by some stimulus emanating from misplaced epithelium, by muscle misarrangement, or by aberrant growth invading and distorting normal muscle [1]. Martin et al. [17] compared adenomyoma of the vaterian system to its gallbladder counterpart and claimed that the former is a lesion developed in diverticula, accompanied by reactive muscle hyperplasia and secondary gland formation, which leads to poorly defined lobules. Fernandez-Cruz and Pera [18] considered adenomyoma as part of an involutive process of fibroadenomatous type due to increasing age. Other authors, such as Narita and Yokoyama [19], stress the possibly inflammatory nature of this lesion.

\section{Conclusion}

Adenomyomatosis of $\mathrm{CBD}$ and $\mathrm{AV}$ are rare benign lesions, which pose a diagnostic challenge, as they often present with biliary obstruction and mimic malignant neoplasms; imaging and endoscopy rarely offer a definitive diagnosis. As a consequence, in most cases, patients are treated with extensive surgery despite its benign nature. The development and application of new endoscopic, radiological, and pathological modalities are necessary in order to improve the diagnosis and management of these lesions.

\section{Statement of Ethics}

The patients have given written informed consent to publish the details of their case (including the publication of images).

\section{Conflict of Interest Statement}

The authors have no conflicts of interest to declare.

\section{Funding Sources}

There were no funding sources relevant to this case report.

\section{Author Contributions}

Catarina Gouveia: acquisition and interpretation of clinical data for and drafting of the case report; Catarina Fidalgo and Marília Cravo: conception and design of the case; critically revision of the report; and final approval of the version to be published. Rui Loureiro, Helena Oliveira, and Rui Maio: critical revision of the report and final approval of the version to be published. 
1 Handra-Luca A, Terris B, Couvelard A, Bonte $\mathrm{H}$, Flejou JF. Adenomyoma and adenomyomatous hyperplasia of the Vaterian system: clinical, pathological, and new immunohistochemical features of 13 cases. Mod Pathol. 2003 Jun;16(6): 530-6.

2 Nishimura A, Shirai Y, Hatakeyama K. Segmental adenomyomatosis of the gallbladder predisposes to cholecystolithiasis. J Hepatobiliary Pancreat Surg. 2004;11(5):342-7.

3 Bricker DL, Halpert B. Adenomyoma of the gallbladder. Surgery. 1963 May;53:615-20.

4 Albores-Saavedra J, Henson DE, Sobin LH. The WHO histological classification of tumors of the gallbladder and extrahepatic bile ducts. A commentary on the second edition. Cancer. 1992 Jul;70(2):410-4.

5 Baggenstoss AH. Major duodenal papilla: variations of pathologic interest and lesions of the mucosa. Arch Pathol (Chic). 1938;26:853-68.

6 Dardinski VJ. Inflammatory adenomatoid hyperplasia of the major duodenal papilla in man. Am J Pathol. 1931 Sep;7(5):519-522.1.

7 Menzel J, Poremba C, Dietl KH, Böcker W, Domschke W. Tumors of the papilla of Vaterinadequate diagnostic impact of endoscopic forceps biopsies taken prior to and following sphincterotomy. Ann Oncol. 1999 Oct;10(10): 1227-31.

8 Hammarström LE, Holmin T, Stenram U. Adenomyoma of the ampulla of Vater: an uncommon cause of bile duct obstruction. Surg Laparosc Endosc. 1997 Oct; 7(5):388-93.

9 Navaneethan U, Njei B, Lourdusamy V, Konjeti R, Vargo JJ, Parsi MA. Comparative effectiveness of biliary brush cytology and intraductal biopsy for detection of malignant biliary strictures: a systematic review and meta-analysis. Gastrointest Endosc. 2015 Jan;81(1):168-76.

10 Kim JY, Choi JH, Kim JH, Kim CL, Bae SH, Choi YK, et al. [Clinical usefulness of bile cytology obtained from biliary drainage tube for diagnosing cholangiocarcinoma]. Korean J Gastroenterol. 2014 Feb;63(2):107-13. Korean.

11 Uchida N, Kamada H, Ono M, Aritomo Y, Masaki T, Nakatsu T, et al. How many cytological examinations should be performed for the diagnosis of malignant biliary stricture via an endoscopic nasobiliary drainage tube? J Gastroenterol Hepatol. 2008 Oct;23(10):1501-4.

12 Logrono R, Kurtycz DF, Molina CP, Trivedi VA, Wong JY, Block KP. Analysis of false-negative diagnoses on endoscopic brush cytology of biliary and pancreatic duct strictures: the experience at 2 university hospitals. Arch Pathol Lab Med. 2000 Mar;124(3):387-92.

13 Navaneethan U, Njei B, Venkatesh PG, Lourdusamy V, Sanaka MR. Endoscopic ultrasound in the diagnosis of cholangiocarcinoma as the etiology of biliary strictures: a systematic review and meta-analysis. Gastroenterol Rep (Oxf). 2015 Aug;3(3):209-15.

14 Ogura T, Hara K, Hijioka S, Mizuno N, Imaoka $\mathrm{H}$, Niwa $\mathrm{Y}$, et al. Can endoscopic ultrasoundguided fine needle aspiration offer clinical ben- efit for tumors of the ampulla of vater? -an initial study. Endosc Ultrasound. 2012 Jul;1(2):84-9.

15 Jang KT, Heo JS, Choi SH, Choi D, Lim JH, Oh YL, et al. Adenomyoma of ampulla of Vater or the common bile duct - a report of three cases. Korean J Pathol. 2005;39:59-62.

16 Aoun N, Zafatayeff S, Smayra T, Haddad-Zebouni S, Tohmé C, Ghossain M. Adenomyoma of the ampullary region: imaging findings in four patients. Abdom Imaging. 2005 Jan-Feb; 30(1):86-9.

17 Martin ED, Bedossa P, Oudinot P. Les lésions de la région oddienne: fréquence et association à des lésions biliares et pancréatiques dans une série de 109 autopsies. Gastroenterol Clin Biol. 1987 Aug-Sep;11(8-9):574-80.

18 Fernandez-Cruz L, Pera C. A histological study of the sphincter of Oddi. Proceedings of the 3rd Gastroenterology Symposium; 1976 Jun 8-9; Nice, France. https://doi.org/10.1159/ 000400281.

19 Narita T, Yokoyama M. Adenomyomatous hyperplasia of the papilla of Vater: A sequela of chronic papillitis? Ann Diagn Pathol. 1999 Jun; 3(3):174-7.

20 Ulich TR, Kollin M, Simmons GE, Wilczynski SP, Waxman K. Adenomyoma of the papilla of Vater. Arch Pathol Lab Med. 1987 Apr;111(4): 388-90.

21 Ikei S, Mori K, Yamane T, Katafuchi S, Hirota M, Akagi M. Adenofibromyomatous hyperplasia of the extrahepatic bile duct-a report of two cases. Jpn J Surg. 1989 Sep;19(5):576-82.

22 Legakis NC, Stamatiadis AP, PapadimitriouKarapanou C, Apostolidis NS. Adenomyoma of the common bile duct. Arch Surg. 1990 Apr; 125(4):543.

23 Läuffer JM, Baer HU, Maurer CA, Fröhling S, Scheurer U, Zimmermann A, et al. Adenomyoma of the distal common bile duct mimicking cholangiocarcinoma. Dig Dis Sci. 1998 Jun; 43(6):1200-4.

24 Kalil A, Brodt M, Mastalir E. Adenomioma da papila de Vater em adulto jovem. Rev Col Bras Cir. 2000;27(2):138-9.

25 Tsukamoto T, Kinoshita H, Hirohashi K, Kubo $\mathrm{S}$, Tanaka H, Hamba H, et al. Adenomyoma of the common bile duct. Hepatogastroenterology. 1999 May-Jun;46(27):1627-30.

26 Ojima H, Takenoshita S, Nagamachi Y. Adenomyoma of the common bile duct: report of a case. Hepatogastroenterology. 2000 Jan-Feb; 47(31):132-4.

27 Kayahara M, Ohta T, Kitagawa H, Miwa K, Urabe T, Murata T. Adenomyomatosis of the papilla of Vater: a case illustrating diagnostic difficulties. Dig Surg. 2001;18(2):139-42.

28 Bedirli A, Patiroglu TE, Sozuer EM, Sakrak O. Periampullary adenomyoma: report of two cases. Surg Today. 2002;32(11):1016-8.

29 Martínez Vieira A, Durán Ferreras I, Gómez Bravo MA, Tamayo López MJ, García González I, Serrano Díez-Canedo J, et al. Ictericia obstructiva en varón de 22 años. Rev Esp Enferm Dig. 2005 Jun;97(6):460-1.
30 Masoom S, Venkataraman G, Hammadeh R. Symptomatic adenomyoma of the Vaterian system: a pathologic curiosity with a potential for misdiagnosis. APMIS. 2006 Jul-Aug;114(7-8): 559-61.

31 Kwon TH, Park DH, Shim KY, Cho HD, Park $\mathrm{JH}$, Lee SH, et al. Ampullary adenomyoma presenting as acute recurrent pancreatitis. World J Gastroenterol. 2007 May;13(20):2892-4.

32 Shu GM, Wang YJ, Du Z, Li DY, Liu CL. Bile tract adenomyoma: a case report. World J Gastroenterol. 2008 Jan;14(4):647-50.

33 Iwaki K, Shibata K, Ohta M, Endo Y, Uchida H, Tominaga $\mathrm{M}$, et al. Adenomyomatous hyperplasia of the common bile duct: report of a case. Surg Today. 2008;38(1):85-9.

34 Genevay M, Frossard JL, Huber O, RubbiaBrandt L, Dumonceau JM. High-grade common bile duct stricture caused by diffuse adenomyomatosis. Gastrointest Endosc. 2009 May; 69(6):1167-8

35 Lehwald N, Cupisti K, Baldus SE, Kröpil P, Schulte Am Esch J 2nd, Eisenberger CF, et al. Unusual histological findings after partial pancreaticoduodenectomy including benign multicystic mesothelioma, adenomyoma of the ampulla of Vater, and undifferentiated carcinoma, sarcomatoid variant: a case series. J Med Case Reports. 2010 Dec;4(1):402.

36 Higashi M, Goto M, Saitou M, Shimizu T, Rousseau K, Batra SK, et al. Immunohistochemical study of mucin expression in periampullary adenomyoma. J Hepatobiliary Pancreat Sci. 2010 May;17(3):275-83.

37 Kumari N, Vij M. Adenomyoma of ampulla: a rare cause of obstructive jaundice. J Surg Case Rep. 2011 Aug;2011(8):6.

38 Choi YH, Kim MJ, Han JH, Yoon SM, Chae HB, Youn SJ, et al. Clinical, pathological, and immunohistochemical features of adenomyoma in the ampulla of vater. Korean J Gastroenterol. 2013 Dec;62(6):352-8.

39 Rafiullah TS, Tanimu S. Adenomyomatous hyperplasia of the ampulla of Vater presenting as acute pancreatitis. BMJ Case Rep. 2014 Mar; 2014 mar06 1:bcr2013203151.

40 Choi JH, Lee SH, Kim JS, Kim J, Shin BS, Jang $\mathrm{DK}$, et al. A case of adenomyomatous hyperplasia of the distal common bile duct mimicking malignant stricture. Korean J Gastroenterol. 2016 Jun;67(6):332-6.

41 D'Assuncao MA, Armellini ST, Moribe D, Nova da Costa LS, Leite GF, Vendrame LM, et al. Adenomyoma of the common bile duct: a rare lesion diagnosed and treated by ERCP. Endoscopy. 2016;48(S 01 Suppl 1):E266-7.

42 Keegan M, Karim R, Kaffes A, Saxena P. A welcome diagnosis for painless biliary dilatation (with video). Gastrointest Endosc. 2017 Sep; 86(3):568-9.

43 Gialamas E, Mormont M, Bagetakos I, Frossard JL, Morel P, Puppa G. Combination of adenomyoma and adenomyomatous hyperplasia of the ampullary system: a first case report. Int J Surg Pathol. 2018 Oct;26(7):644-8. 